\title{
Conversion of the Modulatory Actions of Dopamine on Spinal Reflexes from Depression to Facilitation in $\mathrm{D}_{3}$ Receptor Knock-Out Mice
}

\author{
Stefan Clemens and Shawn Hochman \\ Department of Physiology, Emory University School of Medicine, Atlanta, Georgia 30322
}

Descending monoaminergic systems modulate spinal cord function, yet spinal dopaminergic actions are poorly understood. Using the in vitro lumbar cord, we studied the effects of dopamine and $\mathrm{D}_{2}$-like receptor ligands on spinal reflexes in wild-type $(\mathrm{WT})$ and $\mathrm{D}_{3}$-receptor knock-out mice $\left(\mathrm{D}_{3} \mathrm{KO}\right)$.

Low dopamine levels $(1 \mu \mathrm{M})$ decreased the monosynaptic "stretch" reflex (MSR) amplitude in WT animals and increased it in $\mathrm{D}_{3} \mathrm{KO}$ animals. Higher dopamine concentrations $(10-100 \mu \mathrm{M})$ decreased MSR amplitudes in both groups, but always more strongly in WT. Like low dopamine, the $\mathrm{D}_{3}$ receptor agonists pergolide and PD 128907 reduced MSR amplitude in WT but not $\mathrm{D}_{3} \mathrm{KO}$ mice. Conversely, $\mathrm{D}_{3}$ receptor antagonists (GR 103691 and nafadotride) increased the MSR in WT but not in $\mathrm{D}_{3} \mathrm{KO}$ mice. In comparison, $\mathrm{D}_{2}$-preferring agonists bromocriptine and quinpirole depressed the MSR in both groups. Low dopamine (1-5 $\mu \mathrm{M})$ also depressed longer-latency (presumably polysynaptic) reflexes in WT but facilitated responses in $\mathrm{D}_{3} \mathrm{KO}$ mice. Additionally, in some experiments (e.g., during $10 \mu \mathrm{M}$ dopamine or pergolide in WT), polysynaptic reflexes were facilitated in parallel to MSR depression, demonstrating differential modulatory control of these reflex circuits. Thus, low dopamine activates $\mathrm{D}_{3}$ receptors to limit reflex excitability. Moreover, in $\mathrm{D}_{3}$ ligand-insensitive mice, excitatory actions are unmasked, functionally converting the modulatory action of dopamine from depression to facilitation.

Restless legs syndrome (RLS) is a CNS disorder involving abnormal limb sensations. Because RLS symptoms peak at night when dopamine levels are lowest, are relieved by $\mathrm{D}_{3}$ agonists, and likely involve increased reflex excitability, the $\mathrm{D}_{3} \mathrm{KO}$ mouse putatively explains how impaired $\mathrm{D}_{3}$ activity could contribute to this sleep disorder.

Key words: spinal cord reflex; monoamine; neuromodulation; restless legs syndrome; monosynaptic; mouse model

\section{Introduction}

Spinal cord function is strongly modulated by monoamines (serotonin, dopamine, noradrenaline) (Baldissera et al., 1981; Jordan et al., 1992; Tanaka et al., 1997; Kiehn and Katz, 1999); however, despite a wide body of literature on the roles of serotonin and noradrenaline, there are only few studies on the modulatory actions of dopamine in the spinal cord (Garraway and Hochman, 2001). The sole source for spinal dopamine is the A11 cell group in the dorsal posterior hypothalamus (Skagerberg et al., 1982; Lindvall et al., 1983; Skagerberg and Lindvall, 1985; Holstege et al., 1996). A11 dopaminergic neurons send collaterals throughout most of the spinal cord, but mostly exclude the substantia gelatinosa. Dopaminergic synapses in spinal cord are both synaptic and nonsynaptic, suggesting that dopaminergic signaling is

Received Sept. 7, 2004; revised Nov. 2, 2004; accepted Nov. 6, 2004.

S.C. was supported by a Fellowship award from the Christopher Reeve Paralysis Foundation (CB2-0205-1B). S.H. was supported by National Institute of Neurological Disorders and Stroke Grant NSO45248. We thank Dr. David Rye (Department of Neurology, Emory University School of Medicine, Atlanta, GA) for providing wild-type and $\mathrm{D}_{3} \mathrm{KO}$ mice, Gillian Hue for initiating the breeding colonies, and Dr. Peter Wenner, Kim Dougherty, and David Machacek for comments on this manuscript. We also thank Maggie Hatcher and Megan Daugherty for expert technical assistance.

Correspondence should be addressed to Shawn Hochman, Department of Physiology, Emory University School of Medicine, 615 Michael Street, Atlanta, GA 30322. E-mail: shochman@physio.emory.edu.

DOI:10.1523/JNEUROSCI.3698-04.2004

Copyright $\odot 2004$ Society for Neuroscience ～0270-6474/04/2411337-09\$15.00/0 via both classic synapses and volume transmission (Ridet et al., 1992).

There is extensive evidence for the existence of $\mathrm{D}_{1}, \mathrm{D}_{2}$, and $\mathrm{D}_{3}$ receptors in the spinal cord (van Dijken et al., 1996; Gladwell and Coote, 1999a,b; Gladwell et al., 1999; Levant and McCarson, 2001); however, the contribution of these receptors to spinal reflex excitability is not well known, except that $D_{2}$-like receptor agonists depress monosynaptic "stretch" reflexes (MSRs) in cat and rat (Carp and Anderson, 1982; Gajendiran et al., 1996). We studied the effects of dopamine and $\mathrm{D}_{2}$-like receptor agonists on spinal cord excitability as measured by electrophysiological recordings of spinal reflexes in the mouse, and we compared the effects of dopamine and $\mathrm{D}_{3}$ receptor-specific drugs in wild-type (WT) and $\mathrm{D}_{3}$ receptor knock-out mice $\left(\mathrm{D}_{3} \mathrm{KO}\right)$ to determine the contribution of spinal $\mathrm{D}_{3}$ receptors to dopamine-evoked modulatory actions.

The $\mathrm{D}_{3} \mathrm{KO}$ mouse chosen phenotypically displays hyperactivity, increased locomotor activity, and hypertension (Accili et al., 1996; Asico et al., 1998). This phenotype resembles features of patients with restless legs syndrome (RLS) that express a locomotor-like activity during sleep (termed periodic leg movements) and commonly have hypertension (Ali et al., 1991; Espinar-Sierra et al., 1997). RLS is a CNS disorder that manifests itself with abnormal sensations in the limbs that are reduced 
during motor activity and with a circadian pattern that peaks at night. Intriguingly, hypothalamic dopamine has a circadian rhythm with lowest concentrations observed at night when RLS emerges (Carlsson et al., 1980), and primary treatment for RLS involves agonists with high affinities to $\mathrm{D}_{3}$ receptors, implicating deficits in $\mathrm{D}_{3}$ signaling in the expression of this sleep disorder (Montplaisir et al., 2000; Allen and Earley, 2001; Stiasny et al., 2002).

Here we show that, at low doses, the modulatory response of dopamine on spinal reflexes is converted from depressant in WT to facilitatory in $\mathrm{D}_{3} \mathrm{KO}$ animals because of the loss of $\mathrm{D}_{3}$ receptor function. Thus, $\mathrm{D}_{3}$ receptors are involved in limiting spinal cord excitability. Given our observations in $\mathrm{D}_{3} \mathrm{KO}$ mice, their phenotype, and its correspondence to the RLS phenotype in patients, it is an intriguing possibility that a similar conversion in modulatory actions occurs in patients suffering from RLS.

Some of these data have been published previously in abstract form (Clemens et al., 2003).

\section{Materials and Methods}

All experimental procedures complied with the National Institutes of Health guidelines for animal care and the Emory Institutional Animal Care and Use Committee. $\mathrm{D}_{3} \mathrm{KO}$ mice (B6.129S4-Drd3 ${ }^{\text {tm1Dac }} / \mathrm{J}$; Jackson Laboratory, Bar Harbor, ME), and their associated wild types (C57BL/6 mice) were anesthetized with $10 \%$ urethane $(2 \mathrm{mg} / \mathrm{kg}$, i.p., body weight) and decapitated. Mice ranged in age from postnatal day 5 to 17 . The spinal cord was carefully dissected out of the body cavity and placed in a Sylgard-lined (Dow Corning, Midland, MI) Petri dish in cooled $\left(<4^{\circ} \mathrm{C}\right)$ artificial CSF (ACSF) containing (in $\mathrm{mm}$ ): $125 \mathrm{NaCl}, 2.5 \mathrm{KCl}, 2 \mathrm{CaCl}_{2}, 1$ $\mathrm{MgCl}_{2}, 25$ glucose, $1.25 \mathrm{NaH}_{2} \mathrm{PO}_{4}$, and $26 \mathrm{NaHCO}_{3}$ at a pH of 7.4, oxygenated with $95 \% \mathrm{O}_{2} / 5 \% \mathrm{CO}_{2}$. After the dura mater was opened and removed to facilitate access of ACSF to the cord, dorsal and ventral roots were identified and pinned out with small insect pins. Preparations were left to recover at room temperature for 30-60 min before the onset of experimentation.

To record reflexes, spinal cord preparations were either left intact (in animals $<7$ d old) or hemisected midsagittally (in animals $>1$ week old). The hemisection in the older animals served to better oxygenate the tissue and allow for better access of ACSF. We did not observe any differences in the modulatory actions reported here when comparing these two approaches. Glass suction electrodes were placed on the distal parts of dorsal and ventral roots of lumbar segments L2-L5. After the stability of the electrode connections to the roots was established, dorsal roots were stimulated with current pulses of $500 \mu \mathrm{A}, 100-500 \mu \mathrm{sec}$, to achieve a maximal reflex response, at interstimulus intervals of 30-180 sec. Reflexes were recorded from the corresponding ventral roots, amplified, and digitized with a Digidata 1322A using pClamp 9 software (Axon Instruments, Union City, CA).

To allow comparisons, reflex responses were rectified, and the calculated integrals of these responses were measured and compared between epochs of identical duration before and after drug application. Reflex amplitudes were normalized to the mean of the control values and are reported here as percentage changes from the control (predrug) conditions. Comparisons were made between the averaged amplitudes of the last 10 consecutive reflex responses measured before drug application and 10 consecutive reflex responses during the application, starting at $\sim 10$ min after the drug was added.

Advantage of the transgenic $D_{3}$ receptor knock-out mouse strain used. Several different transgenic forms of $\mathrm{D}_{3} \mathrm{KO}$ mice have been developed using slightly different approaches (Accili et al., 1996; Xu et al., 1997; Jung and Schmauss, 1999), leading to subtle differences in the phenotype of the null-mutants. For instance, the $\mathrm{D}_{3} \mathrm{KO}$ developed by $\mathrm{Xu}$ et al. (1997) expresses only a temporary increase in locomotor behavior in a novel environment; thus compensatory mechanisms may have developed in those mutants to counter the lack of $\mathrm{D}_{3}$ receptor function (Jung et al., 1999). In contrast, the $\mathrm{D}_{3} \mathrm{KO}$ mice used here (Accili et al., 1996) maintain an increased locomotor behavior for extended time periods, are hypertensive (Asico et al., 1998), and consequently may not possess such a mechanism to compensate for the functional loss of the $\mathrm{D}_{3}$ receptor. Therefore, these mice might be better suited to potentially unravel the mechanisms that underlie $\mathrm{D}_{3}$ receptor-dependent actions normally occurring in the spinal cord.

Pharmacology. After a stable response in the ventral roots recordings was established, generally $30-60 \mathrm{~min}$ after onset of the stimulation protocol (at interstimulus intervals of $30-180 \mathrm{sec}$ ), drugs were bath applied in general for durations of $30 \mathrm{~min}$ in their respective carrier substance. Tests for each of these carrier substances (ethanol, DMSO, and $\mathrm{HCl}$ ) in their final concentrations used in the experiments did not lead to any of the effects on the reflex amplitude observed with the drugs (data not shown). Dopamine was bath applied in concentrations ranging from 1 to $100 \mu \mathrm{M}$, whereas the dopamine receptor selective ligands pergolide, bromocriptine, and quinpirole (RBI/Sigma, Natick, MA) were bath applied at concentrations of $1-2 \mu \mathrm{M}$. The $\mathrm{D}_{3}$ selective agonist PD 128907 (Tocris, Ellisville, MO) was bath applied at a concentration of $10 \mu \mathrm{M}$. In contrast, the highly selective $\mathrm{D}_{3}$ receptor selective antagonists GR 103691 and nafadotride (both from Tocris) were applied at concentrations of 100 and $50 \mathrm{~nm}$, respectively. Several drugs were often compared in the same animal. In these cases, after drug applications, we interrupted the stimulation protocol and washed the preparations carefully and thoroughly (three to four times the bath volume over a 3-5 min period) with ACSF and subsequently let the preparation recover from the drug application for an additional $30 \mathrm{~min}$. During this time, we reinstated the stimulation protocol to assess the recovery of the reflex amplitudes. In general, reflex responses returned to predrug amplitudes, and these "recovered" reflex amplitudes in turn became the predrug control of the subsequent drug application. With this protocol we were able to test several drugs per experiment. To exclude potential lingering effects of the drug applications within the spinal cord, we specifically tested whether the order in which the drugs were applied might play a role in the modulatory effects observed; however, we did not find any correlation between the order of the drugs tested and the modulatory effects induced by these drugs (data not shown).

Data analysis. All values are given as mean \pm SE. We used SigmaPlot and SigmaStat (SPSS Science, Chicago, IL) to analyze the data and test for significant differences in the course of an experiment using parametric or nonparametric tests where appropriate. Differences were considered significant if $p<0.05$.

\section{Results}

Reflexes were analyzed from a total of 68 preparations (35 WT and $33 \mathrm{D}_{3} \mathrm{KO}$ mice). Stimulation of the lumbar dorsal roots generally evoked short-latency monosynaptic and longer-latency reflexes (Fig. 1). Up to three different reflex periods could be distinguished based on the start of the monosynaptic (MSR) component: at $0-3 \mathrm{msec}$, at $\sim 15-30 \mathrm{msec}$, and a third epoch starting at $\sim 30 \mathrm{msec}$. In some preparations, however, the longerlatency reflex components overlapped and could not be easily distinguished. Therefore, in this study we chose to divide the reflex response into two epochs only: the monosynaptic reflex at 0-3 msec (Pinco and Lev-Tov, 1993, 1994; Jonas et al., 1998) corresponding to the group I muscle spindle afferent-evoked stretch reflex, and a second epoch from 5-65 msec after the onset of the MSR response, comprising longer-latency and presumably including polysynaptic reflex pathways.

To establish a baseline of the amplitudes of the monosynaptic stretch and longer-latency reflexes in WT and $\mathrm{D}_{3} \mathrm{KO}$ mice, we first compared the amplitudes under control conditions. We found that the mean amplitudes of both MSR and the longerlatency reflexes were similar between WT and $\mathrm{D}_{3} \mathrm{KO}$ mice (Fig. $\left.2 A_{1}, A_{2}\right)$. A rank order comparison revealed that low- and median-reflex amplitudes of WT and $\mathrm{D}_{3} \mathrm{KO}$ responses were similar. In contrast, we observed more large-reflex amplitudes in 

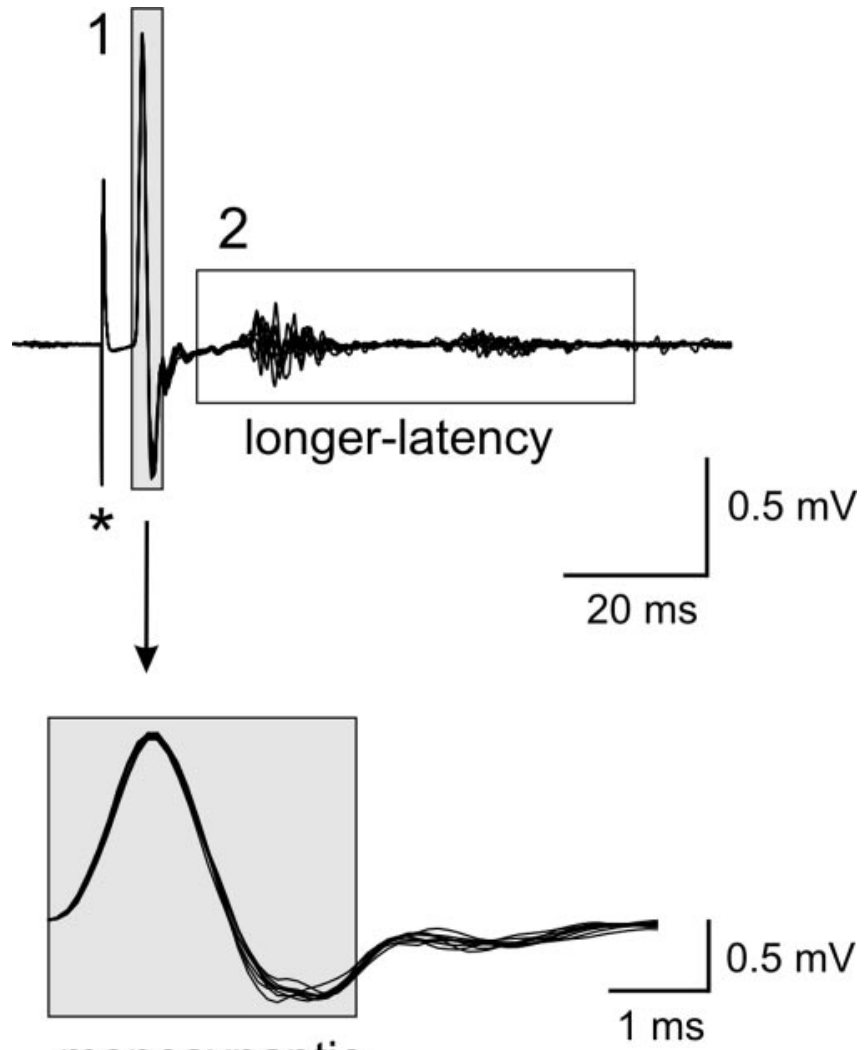

monosynaptic

Figure 1. Example of a reflex response recorded from the ventral roots (10 consecutive sweeps superimposed). Stimulation of an $L 5$ dorsal root ( $500 \mu \mathrm{A}, 500 \mu$ sec, at asterisk) induced a reflex response in the corresponding ventral root that consisted of a monosynaptic (1) and a longer-latency reflex response (2). Note that the longer-latency response consists here of two epochs that can be easily distinguished, at $\sim 15-30$ and $\sim 40-60$ msec after the onset of the MSR, respectively. The boxed regions identify those epochs chosen to calculate the amplitude of monosynaptic and longer-latency reflexes. The MSR component is expanded horizontally to highlight the 3 msec period and show its stability.

$\mathrm{D}_{3} \mathrm{KO}$ animals for both MSR and longer-latency reflex responses when compared with the WT (Fig. $2 B_{1}, B_{2}$ ).

\section{Effects of dopamine on the monosynaptic reflex strength in} $\mathrm{WT}$ and $\mathrm{D}_{3} \mathrm{KO}$ mice

In WT mice, application of $1 \mu \mathrm{M}$ dopamine to the bath generally led to a decrease in the MSR amplitudes (Fig. $3 A_{1}$ ). Specifically, in four of eight experiments, dopamine depressed the reflex amplitude (to $75 \pm 6 \%$ of control) and weakly facilitated it in two experiments ( $109 \pm 5 \%$ of control), leading to an overall decrease to $89 \pm 6 \%$ (Fig. $3 B$ ). In contrast, in $\mathrm{D}_{3} \mathrm{KO}$ mice, application of 1 $\mu \mathrm{M}$ dopamine generally led to an increase in MSR amplitude (Fig. $3 \mathrm{~A}_{2}$ ). There, in five of eight experiments, the size of the MSR increased to $145 \pm 13 \%$ of the control with a decrease observed in only a single experiment. The difference in modulatory actions between $\mathrm{WT}$ and $\mathrm{D}_{3} \mathrm{KO}$ animal populations was significant (Fig. $3 B$ ).

To examine whether the differences in the modulation of the reflex response between $\mathrm{WT}$ and $\mathrm{D}_{3} \mathrm{KOs}$ continued to persist at higher concentrations, we next tested the effects of dopamine applications at 5, 10, 20, 50, and $100 \mu \mathrm{M}$ (Fig. 3B). Application of $5 \mu \mathrm{M}$ dopamine in WT preparations consistently led to a significant depression of the MSR amplitude to $84 \pm 7 \%$ of the control. In contrast, in the $\mathrm{D}_{3} \mathrm{KO}$ animals, in five of eight preparations, dopamine had no effect on the MSR amplitude; it lead to an increase in two additional experiments, and it decreased in one
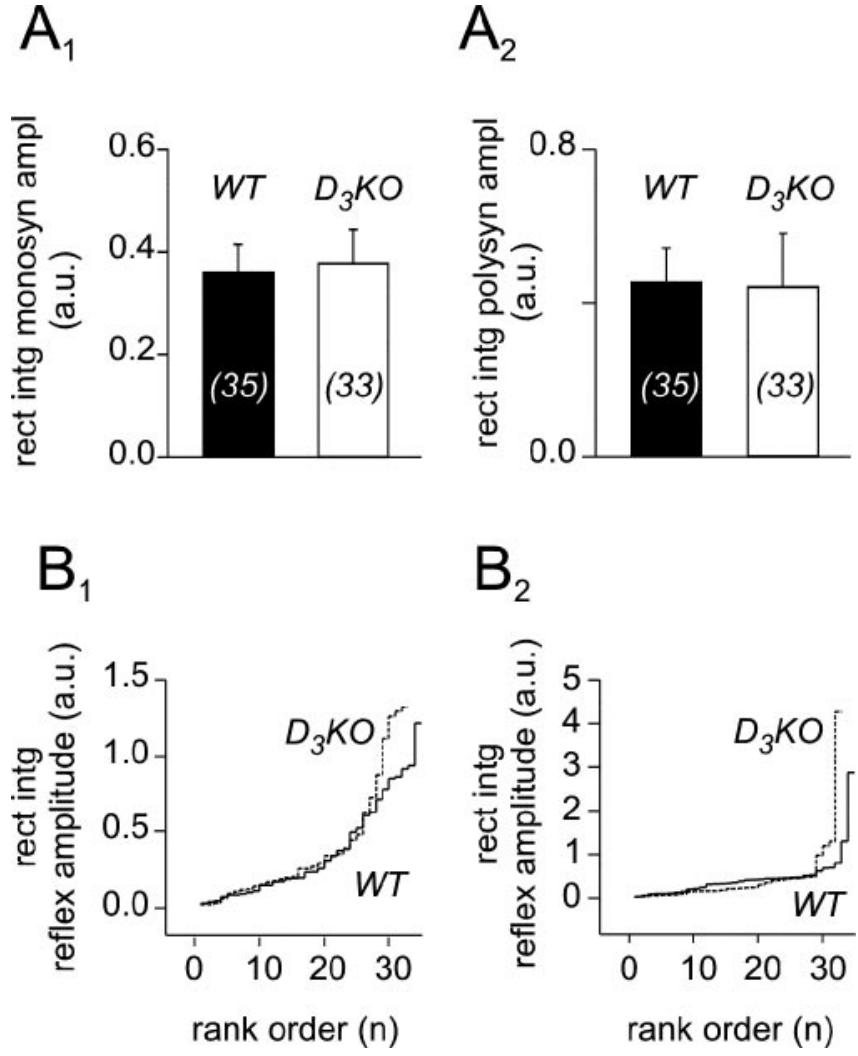

Figure 2. The MSR and longer-latency reflex amplitudes of WT and $D_{3} \mathrm{KO}$ mice have a similar average but a slightly different distribution pattern. $A$, Comparison of the rectified and integrated amplitudes. $A 1$, Monosynaptic reflex amplitudes of wild-type and $\mathrm{D}_{3} \mathrm{KO}$ animals under control conditions. In WT animals, the average is $0.36 \pm 0.05 \mathrm{mV}(n=35)$, and in $\mathrm{D}_{3} \mathrm{KO}$ animals it is $0.38 \pm 0.07 \mathrm{mV}(n=33)$. The populations are not different $(p=0.932)$. A2, Longerlatency reflex amplitudes of WT and $\mathrm{D}_{3} \mathrm{KO}$ animals under control conditions. In WT, the average is $0.44 \pm 0.08 \mathrm{mV}$, and in $D_{3} K 0$ animals it is $0.43 \pm 0.13 \mathrm{mV}$. Again, there is no significant difference between the two populations ( $p=0.948$ ). Sample sizes are indicated within histogram bars in brackets. $B$, Rank ordered histograms of WT and $D_{3} \mathrm{~K} O$ reflex responses. Data are from the same pool as in $A$ and plotted as a function of their rank. B1, Monosynaptic reflex amplitudes. WT (solid line) and $D_{3} \mathrm{KO}$ (dashed line) reflex amplitudes are similar for low and median ranks, but there are more larger-reflex amplitudes in $\mathrm{D}_{3} \mathrm{KO}$ than in WT. B2, Longerlatency reflex amplitudes. Here again, WT (solid line) and $D_{3} \mathrm{KO}$ (dashed line) reflex amplitudes are similar for low and median ranks, and there are more larger-reflex amplitudes in $\mathrm{D}_{3} \mathrm{KO}$ than in WT animals. rect int monosyn ampl, Rectified and integrated monosynaptic reflex amplitude; polysyn ampl, rectified and integrated polysynaptic reflex amplitude; a.u., artificial units.

experiment. Here again, the difference between $\mathrm{WT}$ and $\mathrm{D}_{3} \mathrm{KO}$ animals was significant. At higher concentrations of dopamine, WT animals continued to show a trend to a stronger modulation by dopamine.

\section{Effects of dopamine on the longer-latency reflex strength in WT and $\mathrm{D}_{3} \mathrm{KO}$ mice}

The longer-latency reflex amplitudes were similarly affected by dopamine (Fig. $3 C$ ). Application of $1 \mu \mathrm{M}$ dopamine in WT preparations generally led to a depression of the longer-latency reflex amplitude ( $85 \pm 6 \%$ of control). In contrast, in the $\mathrm{D}_{3} \mathrm{KO}$ animals, dopamine generally induced an increase in reflex strength ( $150 \pm 42 \%$ of control); however, because of the high variability in the $\mathrm{D}_{3} \mathrm{KO}$ dataset, the difference between $\mathrm{WT}$ and $\mathrm{D}_{3} \mathrm{KO}$ animals was not significant ( $p=0.065$ ). At $5 \mu \mathrm{M}$ dopamine, however, at a lower variability of responses from the $\mathrm{D}_{3} \mathrm{KO}$ animals, the longer-latency reflex amplitudes of WT and $\mathrm{D}_{3} \mathrm{KO}$ animals were significantly different, with WT amplitudes depressed to 
$A_{1}$

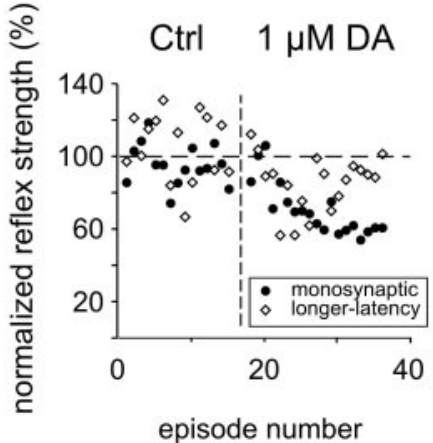

episode number
$\mathrm{A}_{2}$

$D_{3} K O$

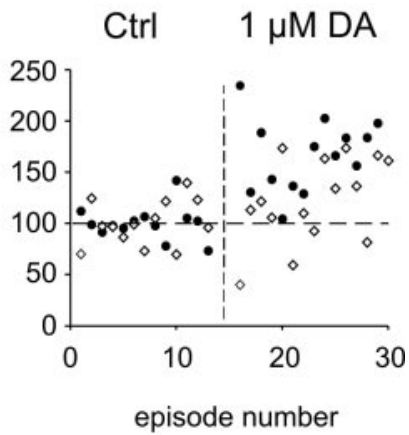

B

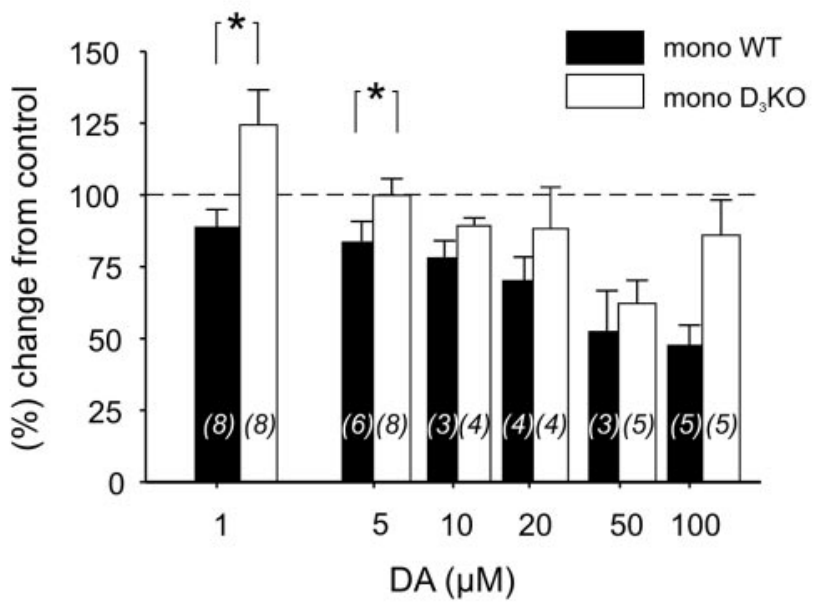

C

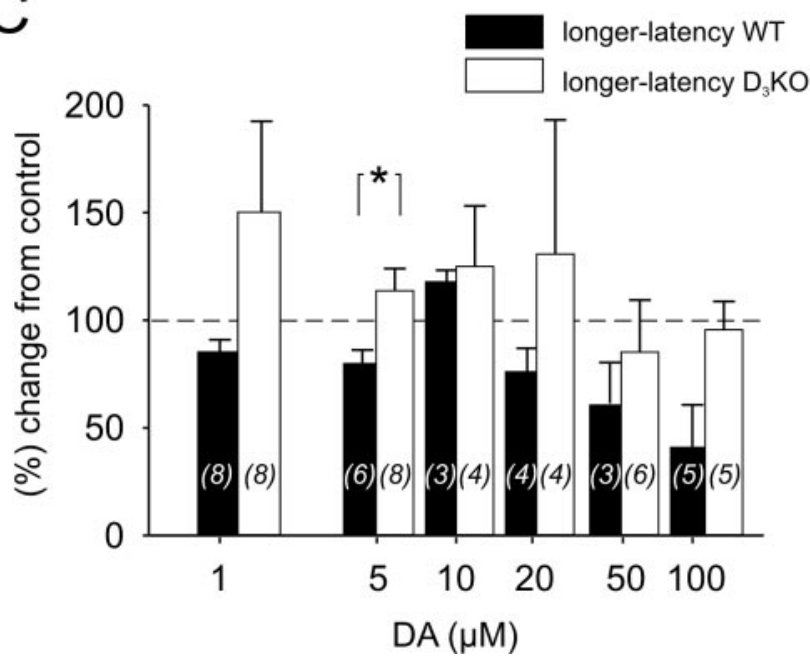

Figure 3. Effects of dopamine (DA) on MSR (mono) and longer-latency reflex amplitudes in WT and $D_{3} \mathrm{KO}$ animals. A1, Typical example of a WT animal, in which application of $1 \mu \mathrm{M}$ dopamine to the bath led to a depression of monosynaptic and longer-latency reflex amplitudes. $A 2$, Example of the effect of bath application of $1 \mu \mathrm{m}$ dopamine to a $D_{3} \mathrm{~K} 0$ animal preparation. Here, MSR and longer-latency amplitude increased during dopamine application. $B_{1}$ Comparison of the dopamine effects on the MSR amplitude at increasing concentrations. At 1 $\mu \mathrm{M}$ dopamine, the MSR amplitude of WT animals decreased, whereas it increased in $D_{3} \mathrm{KO}$ animals. The difference between WT and $\mathrm{D}_{3} \mathrm{KO}$ mice was significant ( $\left.p=0.021\right)$. At $5 \mu \mathrm{M}$ dopamine, there was still a significant difference between the two groups $(p=0.013)$;
$80 \pm 7 \%$ and $\mathrm{D}_{3} \mathrm{KO}$ amplitudes increased to $114 \pm 10 \%$. At 10-100 $\mu \mathrm{M}$ dopamine, as with the MSR, WT animals continued to show a trend to a stronger reflex depression by dopamine than $\mathrm{D}_{3} \mathrm{KO}$ animals.

$\mathrm{D}_{3}$ receptor agonists depress the monosynaptic reflex strength in WT but not in $\mathrm{D}_{3} \mathrm{KO}$ mice

Pergolide is a dopamine receptor agonist with a higher affinity for $\mathrm{D}_{3}$ receptors than for $\mathrm{D}_{2}$ or $\mathrm{D}_{4}$ receptors (Sokoloff et al., 1990, 1992; Millan et al., 2002). In 6 of 11 experiments, application of pergolide to WT mice induced a depression of the MSR amplitude. The overall amplitude decreased to $89 \pm 4 \%$ of the control (Fig. $4 A$ ). In $\mathrm{D}_{3} \mathrm{KO}$ animals, application of pergolide did not depress the MSR amplitude, but led in four of nine experiments to a significant facilitation, with an overall increase of $121 \pm 12 \%$. Moreover, the difference in the amplitude of the MSR between WT and $\mathrm{D}_{3} \mathrm{KO}$ was significant.

Bath application of a second $\mathrm{D}_{3}$ agonist, $\mathrm{PD}$ 128907, modulated the reflex amplitude in a manner similar to pergolide. PD 128907 has a higher affinity to $\mathrm{D}_{3}$ than $\mathrm{D}_{2}$ receptors (Pugsley et al., 1995; Sautel et al., 1995; Cussac et al., 2000), and in WT animals it induced a depression of MSR amplitudes to $88 \pm 6 \%$. In contrast, in the $\mathrm{D}_{3} \mathrm{KO}$ animals, application of PD 128907 led to an overall increase of reflex strength response to $115 \pm 5 \%$. These differences in reflex amplitudes between $\mathrm{WT}$ and $\mathrm{D}_{3} \mathrm{KO}$ animals were also significant (Fig. 4A).

\section{$D_{3}$ receptor antagonists increase the monosynaptic reflex strength in WT but not in $\mathrm{D}_{3} \mathrm{KO}$ mice}

GR 103691 is a potent $D_{3}$ receptor antagonist (Hurley et al., 1996 ), with a $>100$-fold selectivity over $\mathrm{D}_{4}$ receptor sites (Audinot et al., 1998). When applied to the WT spinal cord, it greatly facilitated MSR responses in five of eight experiments, leading to an overall increase to $134 \pm 15 \%$ (Fig. $4 B$ ). In contrast, in $\mathrm{D}_{3} \mathrm{KO}$ animals, GR 103691 did not facilitate the reflex, but rather led to decrease of the amplitude to $87 \pm 4 \%$. The differences in reflex amplitudes between WT and $\mathrm{D}_{3} \mathrm{KO}$ animals were significant (Fig. $4 \mathrm{~B}$ ).

A second $\mathrm{D}_{3}$ antagonist tested, nafadotride, evoked effects in the modulation of the reflex responses similar to the ones observed during application with GR 103691. Nafadotride is a preferential $\mathrm{D}_{3}$ receptor antagonist, with a 10 and 500 times higher affinity over $\mathrm{D}_{2}$ and $\mathrm{D}_{4}$ receptors, respectively (Sautel et al., 1995; Audinot et al., 1998). In three of six WT experiments, nafadotride weakly facilitated the MSR response, leading to an overall increase to $107 \pm 6 \%$. In contrast, and similar to the results obtained during application of GR 103691, nafadotride did not increase the MSR amplitude in any of the four experiments in $\mathrm{D}_{3} \mathrm{KO}$ mice $(92 \pm 2 \%$ ) (Fig. $4 B$ ).

however, the average amplitude in the $\mathrm{D}_{3} \mathrm{~K} 0$ animals was no longer facilitated over the control response. At 10-50 $\mu \mathrm{m}$ dopamine, the reflex amplitudes of both animal types were depressed similarly, although the WT continued to show a slightly stronger depression than the $\mathrm{D}_{3} \mathrm{KO}$ animals. At $100 \mu \mathrm{m}$ dopamine, however, $\mathrm{D}_{3} \mathrm{KO}$ animals showed a noticeably smaller depression than the WT animals. C, Comparison of the dopamine effects on longer-latency reflex amplitudes at increasing dopamine concentrations. At 1 and $5 \mu \mathrm{m}$ dopamine, the reflex amplitude of WT animals generally decreased, whereas the amplitude of $D_{3} \mathrm{KO}$ animals increased. This difference between WT and $D_{3} K 0$ mice was significant at $5 \mu \mathrm{m}(p=0.026)$. At $10-100 \mu \mathrm{M}$ dopamine, the depression observed in WT animals was consistently slightly stronger than in the $\mathrm{D}_{3} \mathrm{KO}$ animals. In this and the following figures, sample sizes are indicated within histogram bars in brackets. All comparisons are based on ANOVA with Tukey or Dunn's post hoc comparison. Asterisks denote significant differences. 
A

\section{$D_{3}$ agonists}

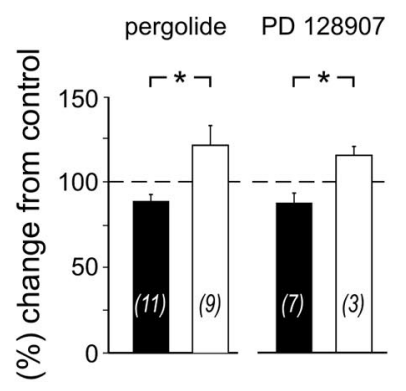

B

$D_{3}$ antagonists

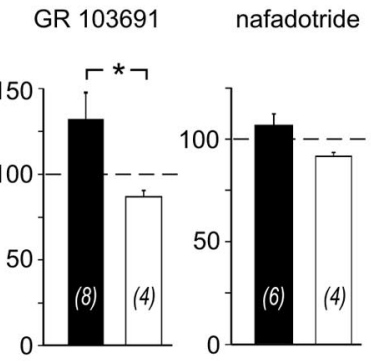

C

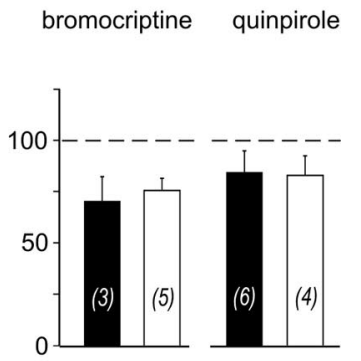

mono WT mono $\mathrm{D}_{3} \mathrm{KO}$

Figure 4. Differential actions of $D_{3}$ receptor ligands on the MSR amplitudes in WT and $D_{3} K 0$ animals. $A, D_{3}$ receptor agonists. Pergolide (left) induced a depression of the amplitude in WT animals (to $89 \pm 4 \%$ ) but led to a facilitation of the reflex amplitude in the $\mathrm{D}_{3} \mathrm{KO}$ animals (to $121 \pm 12 \%$ ), which was significantly different ( $p=0.012$ ). Similarly, PD 128907 (right) also induced a depression of the monosynaptic amplitude in the WT animals (to $88 \pm 6 \%$ ) and a facilitation in the $D_{3} K 0$ animals (to $123 \pm 16 \%$ ). Here again, the differences between the modulatory effects was significant ( $p=0.033) . B, D_{3}$ receptor antagonists. GR 103691 (left) induced a facilitation of the amplitude in WT animals (to $134 \pm 15 \%$ of control) but led to a depression of the reflex amplitude in the $\mathrm{D}_{3} \mathrm{KO}$ animals (to $87 \pm 4 \%$ of control). This difference was significant ( $p=0.029$ ). Similarly, nafadotride (right) also induced a facilitation of the monosynaptic amplitude in the WT animals (to $107 \pm 6 \%$ ), and a depression in the $\mathrm{D}_{3} \mathrm{KO}$ animals (to $92 \pm 2 \%$ ); however, the overall difference was not significant ( $p=0.067$ ). C, D2 receptor agonists. Bromocriptine (left) induced a depression of the amplitude in WT animals (to $70.1 \pm 11.8 \%$ of control) and $\mathrm{D}_{3} \mathrm{KO}$ animals (to $75.4 \pm 5.9 \%$ of control) alike ( $p=1.0)$. Similarly, quinpirole (right) also induced a depression of the monosynaptic amplitude in both WT animals (to $84.3 \pm 10.4 \%$ ) and $\mathrm{D}_{3} \mathrm{KO}$ animals (to $82.8 \pm 9.5 \%$ ), which again was not different $(p=0.914)$.

\section{$D_{2}$ receptor agonists decrease the monosynaptic reflex strength in WT and $\mathrm{D}_{3} \mathrm{KO}$ mice similarly}

The $\mathrm{D}_{3}$ receptor is part of the $\mathrm{D}_{2}$-like receptor family, which consists of $\mathrm{D}_{2}, \mathrm{D}_{3}$, and $\mathrm{D}_{4}$ receptor subtypes. Therefore, to compare the results observed in the $\mathrm{D}_{3} \mathrm{KO}$ mouse during the application of dopamine with another $\mathrm{D}_{2}$-like receptor, we tested the effects of two $\mathrm{D}_{2}$-preferring agonists, bromocriptine and quinpirole, on spinal reflex amplitudes. Bromocriptine is a $\mathrm{D}_{2} / \mathrm{D}_{3}$ receptor agonist that expresses a two to three times higher affinity for $\mathrm{D}_{2}$ than $\mathrm{D}_{3}$ receptors when tested with $\left[{ }^{125} \mathrm{I}\right]$ iodosulpride (Sokoloff et al., 1990; Freedman et al., 1994; Sautel et al., 1995) and an approximately six times higher affinity to $\mathrm{D}_{2}$ than $\mathrm{D}_{3}$ receptors when tested with $\left[{ }^{3} \mathrm{H}\right]$ thymidine (Sautel et al., 1995). Quinpirole has been shown to have a 30 times higher affinity to $\mathrm{D}_{2}$ over $\mathrm{D}_{3}$ receptors when cloned from human tissue (Sokoloff et al., 1990; Freedman et al., 1994; Sautel et al., 1995) and a 10 times higher affinity to $\mathrm{D}_{2}$ over $\mathrm{D}_{3}$ receptors when cloned from rat tissue (Sokoloff et al., 1990; Sautel et al., 1995).

Application of bromocriptine consistently led to a decrease in the reflex amplitude in WT (to $70 \pm 12 \%$ of control) and $\mathrm{D}_{3} \mathrm{KO}$ mice $(75 \pm 6 \%)$. Bath application of quinpirole led to results similar to those observed during the bromocriptine experiments. Quinpirole depressed the reflex amplitude to $84 \pm 10 \%$ in WT and $83 \pm 10 \%$ in $\mathrm{D}_{3} \mathrm{KO}$ mice. There was no statistical difference in the datasets between WT and $\mathrm{D}_{3} \mathrm{KO}$ animals for either drug (Fig. 4C).

\section{Monosynaptic and longer-latency reflexes can be modulated differentially by dopaminergics}

We observed in a number of experiments $(n=22)$ that the monosynaptic and longer-latency reflexes were modulated differently by the dopaminergics, or even in an opposite manner (Fig. 5A). Longer-latency reflexes include a contribution from polysynaptic pathways that involve recruitment of other afferent
$D_{2}$ agonists

modalities and interposed interneurons (e.g., those involved in generating the flexion reflex). It is possible that dopaminergic modulatory actions differ between MSR and longer-latency reflex pathways. Generally, in these cases the MSR was depressed, whereas the longer-latency reflex was facilitated. The variability of these results was quite high and not statistically significant at most of the dopamine concentrations tested; however, at $10 \mu \mathrm{M}$ dopamine, opposite modulatory actions were consistent and significant in WT (Fig. $5 B$ ). In $\mathrm{D}_{3} \mathrm{KO}$ mice, however, we did not observe any consistent differences in the dopaminergic modulation of monosynaptic and longer-latency reflexes, although the longer-latency reflex displayed a tendency toward facilitation rather than depression in the range from 1 to $20 \mu \mathrm{M}$ dopamine (Fig. $5 C$ ). The $\mathrm{D}_{2}$ receptorpreferring agonists bromocriptine and quinpirole did not induce any differential modulation of monosynaptic and longerlatency reflexes in $\mathrm{WT}$ or $\mathrm{D}_{3} \mathrm{KO}$ mice (data not shown); however, such differential actions were again evident with the use of $\mathrm{D}_{3}$ receptor-selective ligands. In WT mice, the $\mathrm{D}_{3}$ receptor agonist pergolide depressed monosynaptic but facilitated longer-latency reflexes (Fig. $6 \mathrm{~A}$ ), whereas in $\mathrm{D}_{3} \mathrm{KO}$ animals a similar result was obtained with the $\mathrm{D}_{3}$ antagonist GR 103691 (Fig. 6B).

\section{Discussion}

This study examined the concentration-dependent actions of dopamine as well as the actions of selective ligands for $\mathrm{D}_{2}$ and $\mathrm{D}_{3}$ receptors on monosynaptic and longer-latency reflexes in WT and $\mathrm{D}_{3} \mathrm{KO}$ mice. Receptor identity of pharmacological actions was verified by testing two different drugs each for $\mathrm{D}_{3}$ agonists, antagonists, and $\mathrm{D}_{2}$ agonists. Overall, our results demonstrate that $\mathrm{D}_{2}$ and $\mathrm{D}_{3}$ receptors provide considerable modulatory control of spinal cord reflex excitability. Furthermore, loss of $\mathrm{D}_{3}$ receptor activity can result in a conversion of the modulatory actions of dopamine from depression to facilitation.

\section{Modulatory effects of dopaminergics on spinal reflex amplitudes}

Our data indicate that dopamine as low as $1 \mu \mathrm{M}$ can depress the monosynaptic stretch reflex in WT animals. This depression is likely attributable to $D_{3}$ receptor activation because (1) dopamine binds to $\mathrm{D}_{3}$ receptors with very high affinity (Sokoloff et al., 1992; Freedman et al., 1994; Sautel et al., 1995), (2) $\mathrm{D}_{3}$ agonists depress reflexes, and (3) reflex depression at low dopamine or with $\mathrm{D}_{3}$ agonists is lost in the $\mathrm{D}_{3} \mathrm{KO}$ animals. Thus, $\mathrm{D}_{3}$ receptors may tonically control spinal dopaminergic modulatory actions during conditions of minimal activity.

Although we did not try doses of dopamine $<1 \mu \mathrm{M}$, dopamine has highest affinity for the $\mathrm{D}_{3}$ receptor with reported $K_{\mathrm{d}}$ values averaging $\sim 25$ nM (Sokoloff et al., 1992; Freedman et al., 1994; Sautel et al., 1995). Interestingly, microdialysis data suggest that dopamine is found in the extracellular space in the $\sim 10 \mathrm{~nm}$ range (Smith et al., 1992), supporting the possibility of a tonic control of reflex strength via $D_{3}$ receptor activation. Evidence that $D_{3}$ 
receptors are tonically modulating spinal reflexes is provided by the following two observations. First, under control conditions, we observed a greater incidence of large-reflex amplitudes in $\mathrm{D}_{3} \mathrm{KO}$ than in WT animals. Second, in the absence of exogenously applied dopamine, $\mathrm{D}_{3}$ receptor antagonists facilitate reflex strength in WT but not $\mathrm{D}_{3} \mathrm{KO}$ mice. Tonic $\mathrm{D}_{3}$ receptor activity could occur either by constitutive activity in the absence of ligand (Tiberi and Caron, 1994) or by continued dopamine release from descending terminals after the isolation of the spinal cord. Hadjiconstantinou et al. (1984) demonstrated that another descending monoamine, serotonin, remains in the spinal cord for $>1$ week after spinal transection. Thus, low levels of endogenously released dopamine could serve to tonically regulate synaptic gain of primary afferent input.

In contrast to the depression observed in WT at low dopamine concentrations, modulatory actions were transformed into facilitation in $\mathrm{D}_{3} \mathrm{KO}$ mice. This change was attributable to the lack of a functional $D_{3}$ receptor because $D_{3}$ receptors ligand actions were altered concomitantly. In the absence of functional $\mathrm{D}_{3}$ receptors in $\mathrm{D}_{3} \mathrm{KO}$ mice, the observed net facilitatory effect at low dopamine concentrations might be channeled via an unmasking of facilitatory actions of $\mathrm{D}_{1}$-like receptor activity (Barasi and Roberts, 1977; Smith et al., 1995; Mizuo et al., 2004). For example, $\mathrm{D}_{1}$ and $\mathrm{D}_{3}$ receptors are coexpressed in neurons of the nucleus accumbens and the islands of Calleja (Le Moine and Bloch, 1996; Ridray et al., 1998; Schwartz et al., 1998), can form heterodimers that coregulate each other (Karasinska et al., 2000), and can induce opposite actions within the same cell (Ridray et al., 1998; Schwartz et al., 1998).

Thus, although dopamine has higher affinity for $\mathrm{D}_{3}$ over $\mathrm{D}_{1}$ receptors when tested in binding studies (Billard et al., 1984; Sokoloff et al., 1992), it might be possible that, in the absence of $\mathrm{D}_{3}$ receptors, low dopamine ( 1 and $5 \mu \mathrm{M}$ ) activates a sufficient number of $\mathrm{D}_{1}$-like receptors to exert facilitatory physiological actions.

At higher dopamine concentrations, other receptor activity, including the $\mathrm{D}_{2}$ receptor, might contribute to an overall reflex depression observed in WT and $\mathrm{D}_{3} \mathrm{KO}$. Dopamine has on average a $>10$ times lower affinity to $D_{2}$ over $D_{3}$ receptors (Imafuku, 1987; Freedman et al., 1994). Thus, at higher dopamine concentrations $(>10-100 \mu \mathrm{M}), \mathrm{D}_{2}$ receptors are likely contributing to the reflex depression observed in WT and $\mathrm{D}_{3} \mathrm{KO}$ mice, which would be expected to be similar between the two mice groups. This hypothesis is validated by the fact that $\mathrm{D}_{2}$ receptor agonists depress the monosynaptic reflexes in WT and $\mathrm{D}_{3} \mathrm{KO}$ mice correspondingly.

For longer-latency reflexes, dopamine also predominantly depressed reflex amplitude in $\mathrm{WT}$, whereas in $\mathrm{D}_{3} \mathrm{KO}$ mice, lower dopamine actions (1-20 $\mu \mathrm{M})$ were generally facilitatory. Thus, $\mathrm{D}_{3}$ receptors also reduce longer-latency reflex strength, and in their absence, facilitatory actions are unmasked. In contrast, $\mathrm{D}_{2}$ receptor agonists depressed MSR and longer-latency reflex components similarly in WT and $\mathrm{D}_{3} \mathrm{KO}$ animals.

Longer-latency responses may be attributable to (1) activation of other afferent fibers including $\mathrm{A} \delta$ and $\mathrm{C}$ fibers (Lozier and Kendig, 1995; Hedo and Lopez-Garcia, 2002), (2) repetitive firing in motoneuron pools, and/or (3) activation of interneuronal pathways. Because we observed a differential modulation of short- and longer-latency reflexes, we assume that at least some of the longer-latency actions are via intercalated interneurons; however, because there are multiple spinal interneuronal populations that can be responsible for these actions (Baldissera et al., 1981; Jankowska, 1992), their identity cannot be determined with any certainty. In those cases in which we were able to clearly distinguish two longer-latency reflex components, no differential modulatory responses were observed (data not shown).

Opposite modulatory actions, even within the same experi- 
A

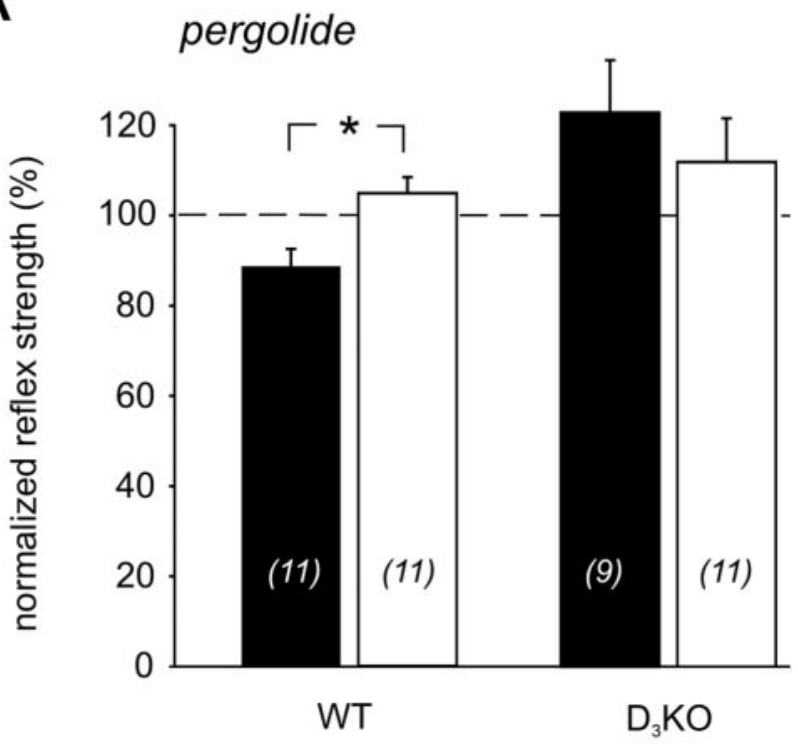

GR 103691

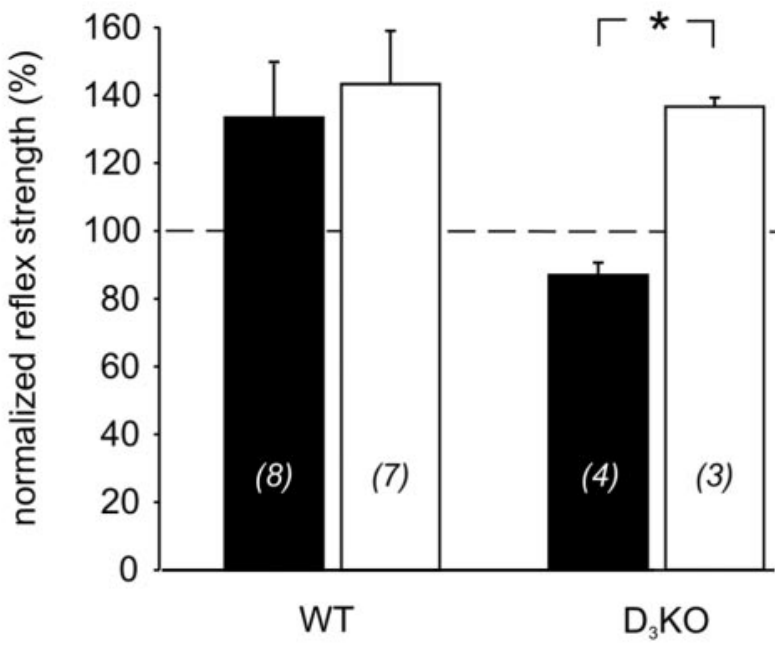

monosynaptic longer-latency

Figure 6. Differential actions of $D_{3}$ receptor-specific drugs on the monosynaptic and longerlatency reflex amplitudes in WT and $D_{3} K 0$ animals. $A$, The $D_{3}$ receptor agonist pergolide induced a depression of the monosynaptic amplitude (black) in WT animals (to $89 \pm 4 \%$ of control), but also led to a facilitation of the longer-latency reflex amplitude (white) (to $105 \pm 4 \%$ of control; $p=0.007)$. There was no such difference in the effects of pergolide in $D_{3} K 0$ animals. $B_{\text {, Con- }}$ versely, in $D_{3} K 0$ but not WT animals, the $D_{3}$ receptor antagonist GR 103691 induced a depression of the monosynaptic amplitude (to $87 \pm 4 \%$ ) and a facilitation of the longer-latency reflex amplitude (to $137 \pm 3 \%$ ), which also was different $(p<0.001)$.

ment, were observed between MSR (depression) and longerlatency reflexes (facilitation) with $10 \mu \mathrm{M}$ dopamine and with $\mathrm{D}_{3}$ but not $\mathrm{D}_{2}$ receptor ligands. Thus, dopaminergics appear to exert a differential control on reflex pathways at least partly via actions at $D_{3}$ but not $D_{2}$ receptors. These differences may be the result of different distributions of the dopamine receptor subtypes in conjunction with different affinities for dopamine. Thus, spinal cord reflex function may be modified in different ways depending on receptor activation identity (Joyce et al., 2002). For example, differential actions of dopaminergics on spinal circuitry have been observed previously in the lamprey cord, in which dopamine depressed polysynaptic IPSPs, whereas polysynaptic excitatory potentials were unaltered (Kemnitz, 1997).

\section{Previous studies on actions of dopamine related to spinal cord reflex function}

In comparison with serotonin and noradrenaline, the modulatory actions of dopamine in the spinal cord are modest (Garraway and Hochman, 2001). This could explain the variability and often weak modulatory actions in some of the datasets reported here. Dopamine has been shown to directly increase the excitability of rat motoneurons (Barasi and Roberts, 1977), and in cultured embryonic chick motoneurons, it enhances kainate-evoked currents by a $\mathrm{D}_{1}$-like, PKA-sensitive mechanism (Smith et al., 1995). In cat and rat it has been shown that $\mathrm{D}_{2}$-like receptors depress the amplitude of muscle spindle activation-evoked monosynaptic reflexes (Carp and Anderson, 1982; Gajendiran et al., 1996), but the effects of longer-latency reflex responses were not reported. The reported actions may take place on the primary afferents themselves, because dopamine has direct actions in primary afferents in frog (Ryan et al., 1985) and can depolarize dorsal root ganglia (DRG) neurons (Gallagher et al., 1980) via $\mathrm{D}_{1}$-like receptors and hyperpolarize via $\mathrm{D}_{2}$-like receptors (Abramets and Samoilovich, 1991). Moreover, dopamine depresses $\mathrm{Ca}^{2+}$ currents in isolated DRG neurons (Formenti et al., 1998), an observation that may support a dopamine-induced reduction in sensory input by presynaptic mechanisms.

\section{Hypothalamic dopamine, circadian variation, and RLS}

The A11 region provides the only dopaminergic input to the rat spinal cord (Skagerberg and Lindvall, 1985) with very similar projections in rat, cat, and monkey (Holstege et al., 1996) and levels in cat (Fleetwood-Walker and Coote, 1981) and human (Commissiong and Sedgwick, 1975). Hypothalamic dopamine content has a strong circadian variation (Huie et al., 1989) already observed in the neonatal rat (Macho et al., 1986). In human tissue it was shown that hypothalamic dopamine peaks between 3 and 6 P.M. and then drops continuously to reach its nadir in early morning (Carlsson et al., 1980). Thus, superimposed on circadian fluctuations in dopamine release, low dopamine could preferentially activate high-affinity $D_{3}$ receptors at night, to reduce sensory responsiveness and motoneuron excitability. In contrast, during daytime with dopamine levels increased, facilitatory $\mathrm{D}_{1}$ receptor activity (Barasi and Roberts, 1977; Smith et al., 1995) could overwhelm the depressant actions and exert a net increase in spinal reflex gain (as observed with $10 \mu \mathrm{M}$ dopamine) (Fig. $3 C$ ). Circadian cycling of $\mathrm{D}_{2}$-like and $\mathrm{D}_{1}$-like receptor gene expression has been observed recently in motor regions of the rat brain (Weber et al., 2004), and if also present in the spinal cord it might be timed to complement changes in concentrations of hypothalamic dopamine release. A functional consequence of such a coordinated action would be an optimized sensorimotor responsiveness tuned to the behavioral state of the animal.

Our results suggest that $\mathrm{D}_{3}$ receptors are involved in tonically limiting spinal cord excitability and may provide insight into the consequences of $\mathrm{D}_{3}$ receptor dysfunction. For example, $\mathrm{D}_{3}$ receptor dysfunction is implicated in individuals suffering from RLS. RLS is a CNS disorder involving abnormal limb sensations that peak at night when dopamine levels are at their lowest. RLS likely involves increased spinal cord reflex excitability (Bara-Jimenez et al., 2000) and is relieved best by $\mathrm{D}_{3}$ receptor-preferring agonists 
(Montplaisir et al., 2000). Intriguingly, however, there exists no animal model for RLS. Because the modulatory action of low dopamine is converted from depression to facilitation in an animal that lacks a functional $\mathrm{D}_{3}$ receptor, the $\mathrm{D}_{3} \mathrm{KO}$ mouse identifies one explanation of how reduced $\mathrm{D}_{3}$ activity could contribute to the increased reflex excitability seen in RLS, thus representing a relevant model to address these questions in more detail. It is important to be aware, however, that in patients with RLS, $\mathrm{D}_{3}$ receptor agonists commonly have a therapeutic benefit, suggesting that RLS is not caused by $\mathrm{D}_{3}$ receptor dysfunction but rather by reduced $\mathrm{D}_{3}$ receptor activation.

In summary, the $\mathrm{D}_{3} \mathrm{KO}$ mouse identifies the role and the importance of $\mathrm{D}_{3}$ receptors in modulating spinal cord excitability. Spinal dopamine actions originate from the hypothalamus and so are expected to vary with a circadian profile. Because dopamine projections can be found in autonomic, sensory, and motor systems, it is likely that dopamine regulates excitability in an integrative manner, to adjust spinal cord function within a physiological range appropriate for the animal's state.

\section{References}

Abramets II, Samoilovich IM (1991) Analysis of two types of dopaminergic responses of neurons of the spinal ganglia of rats. Neurosci Behav Physiol 21:435-440.

Accili D, Fishburn CS, Drago J, Steiner H, Lachowicz JE, Park BH, Gauda EB, Lee EJ, Cool MH, Sibley DR, Gerfen CR, Westphal H, Fuchs S (1996) A targeted mutation of the D3 dopamine receptor gene is associated with hyperactivity in mice. Proc Natl Acad Sci USA 93:1945-1949.

Ali NJ, Davies RJ, Fleetham JA, Stradling JR (1991) Periodic movements of the legs during sleep associated with rises in systemic blood pressure. Sleep 14:163-165.

Allen RP, Earley CJ (2001) Restless legs syndrome: a review of clinical and pathophysiologic features. J Clin Neurophysiol 18:128-147.

Asico LD, Ladines C, Fuchs S, Accili D, Carey RM, Semeraro C, Pocchiari F, Felder RA, Eisner GM, Jose PA (1998) Disruption of the dopamine D3 receptor gene produces renin-dependent hypertension. J Clin Invest 102:493-498.

Audinot V, Newman-Tancredi A, Gobert A, Rivet JM, Brocco M, Lejeune F, Gluck L, Desposte I, Bervoets K, Dekeyne A, Millan MJ (1998) A comparative in vitro and in vivo pharmacological characterization of the novel dopamine D3 receptor antagonists (+)-S 14297, nafadotride, GR 103,691 and U 99194. J Pharmacol Exp Ther 287:187-197.

Baldissera F, Hultborn H, Illert M (1981) Integration in spinal neuronal systems. In: Handbook of physiology—the nervous system II, Vol 2, pp 509-595. Baltimore: Williams and Wilkins.

Bara-Jimenez W, Aksu M, Graham B, Sato S, Hallett M (2000) Periodic limb movements in sleep: state-dependent excitability of the spinal flexor reflex. Neurology 54:1609-1616.

Barasi S, Roberts MT (1977) Responses of motoneurones to electrophoretically applied dopamine. Br J Pharmacol 60:29-34.

Billard W, Ruperto V, Crosby G, Iorio LC, Barnett A (1984) Characterization of the binding of $3 \mathrm{H}-\mathrm{SCH} 23390$, a selective D-1 receptor antagonist ligand, in rat striatum. Life Sci 35:1885-1893.

Carlsson A, Svennerholm L, Winblad B (1980) Seasonal and circadian monoamine variations in human brains examined post mortem. Acta Psychiatr Scand [Suppl] 280:75-85.

Carp JS, Anderson RJ (1982) Dopamine receptor-mediated depression of spinal monosynaptic transmission. Brain Res 242:247-254.

Clemens S, Hue G, Sawchuk M, Zhu H, Hochman S (2003) Expression of dopamine $\mathrm{D} 2$ and $\mathrm{D} 3$ receptors and actions of dopaminergics on spinal circuits in wild-type and D3 knock-out mice. Soc Neurosci Abstr 29:186.3.

Commissiong JW, Sedgwick EM (1975) Letter: dopamine and noradrenaline in human spinal cord. Lancet 1:347.

Cussac D, Newman-Tancredi A, Sezgin L, Millan MJ (2000) [ $\left.{ }^{3} \mathrm{H}\right]$ S33084: a novel, selective and potent radioligand at cloned, human dopamine D3 receptors. Naunyn Schmiedebergs Arch Pharmacol 361:569-572.

Espinar-Sierra J, Vela-Bueno A, Luque-Otero M (1997) Periodic leg movements in sleep in essential hypertension. Psychiatry Clin Neurosci 51:103-107.
Fleetwood-Walker SM, Coote JH (1981) Contribution of noradrenaline-, dopamine- and adrenaline-containing axons to the innervation of different regions of the spinal cord of the cat. Brain Res 206:95-106.

Formenti A, Martina M, Plebani A, Mancia M (1998) Multiple modulatory effects of dopamine on calcium channel kinetics in adult rat sensory neurons. J Physiol (Lond) 509:395-409.

Freedman SB, Patel S, Marwood R, Emms F, Seabrook GR, Knowles MR, McAllister G (1994) Expression and pharmacological characterization of the human D3 dopamine receptor. J Pharmacol Exp Ther 268:417-426.

Gajendiran M, Seth P, Ganguly DK (1996) Involvement of the presynaptic dopamine D2 receptor in the depression of spinal reflex by apomorphine. NeuroReport 7:513-516.

Gallagher JP, Inokuchi H, Shinnick-Gallagher P (1980) Dopamine depolarisation of mammalian primary afferent neurones. Nature 283:770-772.

Garraway SM, Hochman S (2001) Modulatory actions of serotonin, norepinephrine, dopamine, and acetylcholine in spinal cord deep dorsal horn neurons. J Neurophysiol 86:2183-2194.

Gladwell SJ, Coote JH (1999a) Fast excitatory postsynaptic potentials and their response to catecholaminergic antagonists in rat sympathetic preganglionic neurones in vitro. Neurosci Lett 268:89-92.

Gladwell SJ, Coote JH (1999b) Inhibitory and indirect excitatory effects of dopamine on sympathetic preganglionic neurones in the neonatal rat spinal cord in vitro. Brain Res 818:397-407.

Gladwell SJ, Pyner S, Barnes NM, Coote JH (1999) D(1)-like dopamine receptors on retrogradely labeled sympathoadrenal neurones in the thoracic spinal cord of the rat. Exp Brain Res 128:377-382.

Hadjiconstantinou M, Panula P, Lackovic Z, Neff NH (1984) Spinal cord serotonin: a biochemical and immunohistochemical study following transection. Brain Res 322:245-254.

Hedo G, Lopez-Garcia JA (2002) 5-HT(1B) but not 5-HT(6) or 5-HT(7) receptors mediate depression of spinal nociceptive reflexes in vitro. Br J Pharmacol 135:935-942.

Holstege JC, van Dijken H, Bujis RM, Goedkengt H, Gosenes T, Bongers CMH (1996) Distribution of dopamine immunoreactivity in the rat, cat, and monkey spinal cord. J Comp Neurol 376:631-652.

Huie JM, Sharma RP, Coulombe Jr RA (1989) Diurnal alterations of catecholamines, indoleamines and their metabolites in specific brain regions of the mouse. Comp Biochem Physiol C 94:575-579.

Hurley MJ, Stubbs CM, Jenner P, Marsden CD (1996) Dopamine D3 receptors are not involved in the induction of c-fos mRNA by neuroleptic drugs: comparison of the dopamine D3 receptor antagonist GR103691 with typical and atypical neuroleptics. Eur J Pharmacol 318:283-293.

Imafuku J (1987) The characterization of $\left[{ }^{3} \mathrm{H}\right]$ sulpiride binding sites in rat striatal membranes. Brain Res 402:331-338.

Jankowska E (1992) Interneuronal relay in spinal pathways from proprioceptors. Prog Neurobiol 38:335-378

Jonas P, Bischofberger J, Sandkuhler J (1998) Corelease of two fast neurotransmitters at a central synapse. Science 281:419-424.

Jordan LM, Brownstone RM, Noga BR (1992) Control of functional systems in the brainstem and spinal cord. Curr Opin Neurobiol 2:794-801.

Joyce JN, Ryoo HL, Beach TB, Caviness JN, Stacey M, Gurevich EV, Reiser M, Adler CH (2002) Loss of response to levodopa in Parkinson's disease and co-occurrence with dementia: role of D3 and not D2 receptors. Brain Res 955:138-152.

Jung MY, Schmauss C (1999) Decreased c-fos responses to dopamine D(1) receptor agonist stimulation in mice deficient for $\mathrm{D}(3)$ receptors. J Biol Chem 274:29406-29412.

Jung MY, Skryabin BV, Arai M, Abbondanzo S, Fu D, Brosius J, Robakis NK, Polites HG, Pintar JE, Schmauss C (1999) Potentiation of the D2 mutant motor phenotype in mice lacking dopamine D2 and D3 receptors. Neuroscience 91:911-924.

Karasinska JM, George SR, El-Ghundi M, Fletcher PJ, O’Dowd BF (2000) Modification of dopamine $\mathrm{D}(1)$ receptor knockout phenotype in mice lacking both dopamine $\mathrm{D}(1)$ and $\mathrm{D}(3)$ receptors. Eur J Pharmacol 399:171-181.

Kemnitz CP (1997) Dopaminergic modulation of spinal neurons and synaptic potentials in the lamprey spinal cord. J Neurophysiol 77:289-298.

Kiehn O, Katz P (1999) Making circuits dance: neuromodulation of motor systems. In: Beyond neurotransmission (Katz PS, ed), pp 275-317. Oxford: Oxford UP.

Le Moine C, Bloch B (1996) Expression of the D3 dopamine receptor in 
peptidergic neurons of the nucleus accumbens: comparison with the D1 and D2 dopamine receptors. Neuroscience 73:131-143.

Levant B, McCarson KE (2001) D(3) dopamine receptors in rat spinal cord: implications for sensory and motor function. Neurosci Lett 303:9-12.

Lindvall O, Bjorklund A, Skagerberg G (1983) Dopamine-containing neurons in the spinal cord: anatomy and some functional aspects. Ann Neurol 14:255-260.

Lozier AP, Kendig JJ (1995) Long-term potentiation in an isolated peripheral nerve-spinal cord preparation. J Neurophysiol 74:1001-1009.

Macho L, Kvetnansky R, Culman J, Fickova M (1986) Neurotransmitter levels in the hypothalamus during postnatal development of rats. Exp Clin Endocrinol 88:142-150.

Millan MJ, Maiofiss L, Cussac D, Audinot V, Boutin JA, Newman-Tancredi A (2002) Differential actions of antiparkinson agents at multiple classes of monoaminergic receptor. I. A multivariate analysis of the binding profiles of 14 drugs at 21 native and cloned human receptor subtypes. J Pharmacol Exp Ther 303:791-804.

Mizuo K, Narita M, Miyatake M, Suzuki T (2004) Enhancement of dopamine-induced signaling responses in the forebrain of mice lacking dopamine D3 receptor. Neurosci Lett 358:13-16.

Montplaisir J, Denesle R, Petit D (2000) Pramipexole in the treatment of restless legs syndrome: a follow-up study. Eur J Neurol 1[Suppl 7]:27-31.

Pinco M, Lev-Tov A (1993) Modulation of monosynaptic excitation in the neonatal rat spinal cord. J Neurophysiol 70:1151-1158.

Pinco M, Lev-Tov A (1994) Synaptic transmission between ventrolateral funiculus axons and lumbar motoneurons in the isolated spinal cord of the neonatal rat. J Neurophysiol 72:2406-2419.

Pugsley TA, Davis MD, Akunne HC, Mackenzie RG, Shih YH, Damsma G, Wikstrom H, Whetzel SZ, Georgic LM, Cooke LW, Demattos SB, Corbin AE, Glase SA, Wise LD, Dijkstra D, Heffner TG (1995) Neurochemical and functional characterization of the preferentially selective dopamine D3 agonist PD 128907. J Pharmacol Exp Ther 275:1355-1366.

Ridet JL, Sandillon F, Rajaofetra N, Geffard M, Privat A (1992) Spinal dopaminergic system of the rat: light and electron microscopic study using an antiserum against dopamine, with particular emphasis on synaptic incidence. Brain Res 598:233-241.

Ridray S, Griffon N, Mignon V, Souil E, Carboni S, Diaz J, Schwartz JC, Sokoloff P (1998) Coexpression of dopamine D1 and D3 receptors in islands of Calleja and shell of nucleus accumbens of the rat: opposite and synergistic functional interactions. Eur J Neurosci 10:1676-1686.

Ryan GP, Hackman JC, Wohlberg CJ, Davidoff RA (1985) Potential changes of frog afferent terminals in response to dopamine. Brain Res 328:283-290.

Sautel F, Griffon N, Levesque D, Pilon C, Schwartz JC, Sokoloff P (1995) A functional test identifies dopamine agonists selective for D3 versus D2 receptors. NeuroReport 6:329-332.

Schwartz JC, Diaz J, Bordet R, Griffon N, Perachon S, Pilon C, Ridray S, Sokoloff P (1998) Functional implications of multiple dopamine receptor subtypes: the D1/D3 receptor coexistence. Brain Res Brain Res Rev $26: 236-242$.

Skagerberg G, Lindvall O (1985) Organization of diencephalic dopamine neurones projecting to the spinal cord in the rat. Brain Res 342:340-351.

Skagerberg G, Bjorklund A, Lindvall O, Schmidt RH (1982) Origin and termination of the diencephalo-spinal dopamine system in the rat. Brain Res Bull 9:237-244

Smith AD, Olson RJ, Justice Jr JB (1992) Quantitative microdialysis of dopamine in the striatum: effect of circadian variation. J Neurosci Methods 44:33-41.

Smith DO, Lowe D, Temkin R, Jensen P, Hatt H (1995) Dopamine enhances glutamate-activated currents in spinal motoneurons. J Neurosci 15:3905-3912.

Sokoloff P, Giros B, Martres MP, Bouthenet ML, Schwartz JC (1990) Molecular cloning and characterization of a novel dopamine receptor (D3) as a target for neuroleptics. Nature 347:146-151.

Sokoloff P, Andrieux M, Besancon R, Pilon C, Martres MP, Giros B, Schwartz JC (1992) Pharmacology of human dopamine D3 receptor expressed in a mammalian cell line: comparison with D2 receptor. Eur J Pharmacol 225:331-337.

Stiasny K, Oertel WH, Trenkwalder C (2002) Clinical symptomatology and treatment of restless legs syndrome and periodic limb movement disorder. Sleep Med Rev 6:253-265.

Tanaka H, Takahashi S, Oki J (1997) Developmental regulation of spinal motoneurons by monoaminergic nerve fibers. J Peripher Nerv Syst 2:323-332.

Tiberi M, Caron MG (1994) High agonist-independent activity is a distinguishing feature of the dopamine D1B receptor subtype. J Biol Chem 269:27925-27931.

van Dijken H, Dijk J, Voom P, Holstege JC (1996) Localization of dopamine D2 receptor in rat spinal cord identified with immunocytochemistry and in situ hybridization. Eur J Neurosci 8:621-628.

Weber M, Lauterburg T, Tobler I, Burgunder JM (2004) Circadian patterns of neurotransmitter related gene expression in motor regions of the rat brain. Neurosci Lett 358:17-20.

Xu M, Koeltzow TE, Santiago GT, Moratalla R, Cooper DC, Hu XT, White NM, Graybiel AM, White FJ, Tonegawa S (1997) Dopamine D3 receptor mutant mice exhibit increased behavioral sensitivity to concurrent stimulation of D1 and D2 receptors. Neuron 19:837-848. 